\title{
Comparison on the removal of hydrogen sulfide in biotrickling filters inoculated with Thiobacillus thioparus and Acidithiobacillus thiooxidans
}

\author{
Germán Aroca* \\ Escuela de Ingeniería Bioquímica \\ Pontificia Universidad Católica de Valparaíso \\ Av. Brasil 2147 \\ Valparaíso, Chile \\ E-mail: garoca@ucv.cl \\ Homero Urrutia \\ Centro de Biotecnología \\ Universidad de Concepción \\ Barrio Universitario $\mathrm{s} / \mathrm{n}$ \\ Concepción, Chile \\ E-mail:hurrutia@udec.cl

\section{Dariela Núñez} \\ Escuela de Ingeniería Bioquímica \\ Pontificia Universidad Católica de Valparaíso \\ Av. Brasil 2147 \\ Valparaíso, Chile \\ Patricio Oyarzún $\$$ \\ Escuela de Ingeniería Bioquímica \\ Pontificia Universidad Católica de Valparaíso \\ Av. Brasil 2147 \\ Valparaíso, Chile \\ Alejandra Arancibia \\ Escuela de Ingeniería Bioquímica \\ Pontificia Universidad Católica de Valparaíso \\ Av. Brasil 2147 \\ Valparaíso, Chile \\ Karlo Guerrero \\ Escuela de Ingeniería Bioquímica \\ Pontificia Universidad Católica de Valparaíso \\ Av. Brasil 2147 \\ Valparaíso, Chile
}

Financial support: This research was financed by the National Fund for Science and Technology (FONDECYT), Project 1050318, and the Pontificia Universidad Católica de Valparaíso, Grant DI 203.764/2006.

Keywords: Acidithiobacillus thiooxidans, biofilm, biofiltration, hydrogen sulfide, Thiobacillus thioparus.

Present address: "Celulosa Arauco, Planta Sargento Aldea, Concepción, Chile; ${ }^{\circledR}$ Departamento de Biotecnología, Facultad de Ingeniería, Universidad San Sebastián, Cruz 1577, Concepción, Chile.
Abbreviations: PVC: polyvinilclorure
PE: polyethylene
TRS: Total Reduced Sulfur
TZ: tezontle

Emissions of hydrogen sulfide $\left(\mathrm{H}_{2} \mathrm{~S}\right)$ by industrial activities is frequent cause of corrosion and unpleasant odours. Treatment of gaseous emissions contaminated with $\mathrm{H}_{2} \mathrm{~S}$ by biotrickling filters inoculated with single cultures of sulfur oxidizer bacteria exhibit several advantages over physicochemical methods, such as shorter adaptation times and higher removal ability. Biofilms of Thiobacillus thioparus and Acidithiobacillus thiooxidans have proved to exhibit high removal capacities, yet no comparative studies between them have been reported. This article reports the efficiency of biotrickling filters inoculated with $T$. thioparus and $A$.

*Corresponding author 
thiooxidans under similar conditions excepting the $\mathrm{pH}$, that was the optimal for the bacterial growth, for the removal of $H_{2} S$. The support was selected by determining the respirometric coefficients of the biomass. The maximum removal capacity of the biofilter inoculated with $T$. thioparus, operating within the range of $\mathrm{pH}(5.5-7.0)$ was $14 \mathrm{gS} \mathrm{m}^{-3} \mathrm{~h}^{-1}$, lower the value obtained for the biotrickling filter inoculated with A. thiooxidans; $370 \mathrm{gS} \mathrm{m}^{-3} \mathrm{~h}^{-1}$. Therefore, it is concluded that acid biotrickling filter inoculated with $A$. thiooxidans constitute the best strategy to remove $\mathrm{H}_{2} \mathrm{~S}$, with the advantage that the system not require an exhaustive $\mathrm{pH}$ control of the liquid media.

Hydrogen sulfide $\left(\mathrm{H}_{2} \mathrm{~S}\right)$ is being emitted by many industrial activities such as petroleum refining, natural gas and petrochemical plants, craft pulp manufacturing, viscose rayon manufacturing, food processing, tanneries, aerobic and anaerobic wastewater treatments. $\mathrm{H}_{2} \mathrm{~S}$ is a colourless, flammable and highly toxic gas, and heavier than air. Its value of Henry's Law constant for the air-water- $\mathrm{H}_{2} \mathrm{~S}$ system at $25^{\circ} \mathrm{C}$ is $0,41\left(\mathrm{H}_{2} \mathrm{~S}\right.$ concentration in $\operatorname{air} / \mathrm{H}_{2} \mathrm{~S}$ concentration in water). Usually $\mathrm{H}_{2} \mathrm{~S}$ is found in mixture with other organic sulfur compounds such as methanethiol, dimethylsulfide and dimethyldisulfide. This mixture is known as the Total Reduced Sulfur Compounds (TRS) (Ruokojarvi et al. 2000).

The physicochemical methods used at present for the treatment of gaseous emissions containing $\mathrm{H}_{2} \mathrm{~S}$ and reduced sulfur compounds, such as adsorption, absorption, incineration, have relatively high energy requirements and/or high chemical and disposal cost. Several biological processes used to treat gaseous emissions contaminated with TRS, and specifically with $\mathrm{H}_{2} \mathrm{~S}$, have been reported (Jensen and Webb, 1995; Smet et al. 1998).

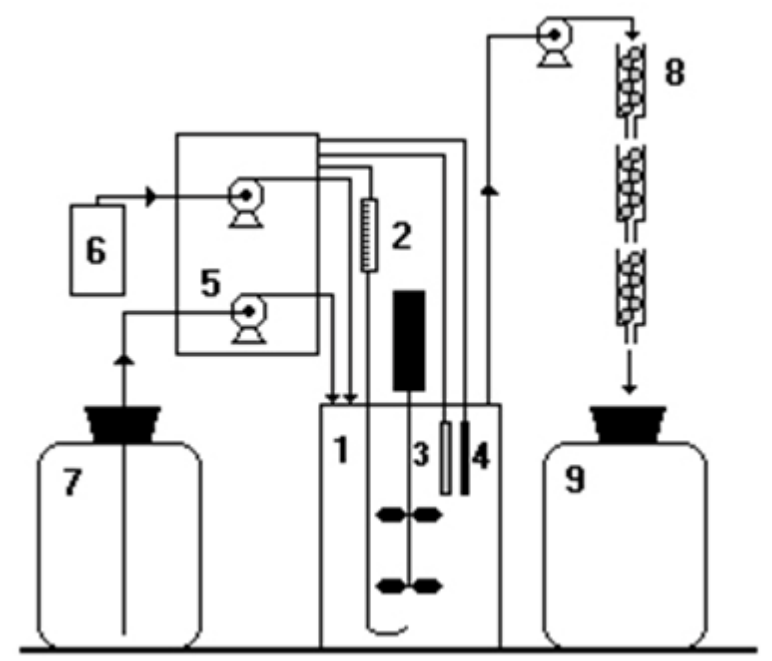

Figure 1. Diagram of the system for generating a biofilm of Thiobacillus thioparus. (1) Bioreactor; (2) Flowmeter; (3) Sensor of $\mathrm{pH}$; (4) Heater; (5) Peristaltic pump; (6) $\mathrm{NaOH}$; (7) Liquid culture medium; (8) Glass columns packed with the carriers; (9) Effluent accumulation.
Biological treatments using biotrickling filters have been proposed as convenient alternatives for treating air streams containing low concentration of contaminants (Deshusses, 1997; Kennes and Thalasso, 1998; Gabriel and Deshusses, 2003). These are packed columns where a bacterial biofilm is formed on the surface of an inert packing material. The contaminated air stream is concurrently or countercurrently contacted with a liquid phase that provides nutrients and conditions to keep the viability and activity of the biofilm. The gas is absorbed in the liquid phase and biologically oxidized, thus converting $\mathrm{H}_{2} \mathrm{~S}$ compounds into oxidized sulfur compounds such as sulfur and sulfate, chemicals that will go out of the bioreactor in the liquid phase (Alonso et al. 1997).

Although it is possible to establish a complex microbial population with the ability to oxidize $\mathrm{H}_{2} \mathrm{~S}$, i.e.: by inoculating the biofilter with biological complex inoculums such as active sludge, a dominating microbial population exhibiting the highest degradation activity develops after a period of adaptation (Hirai et al. 1990; Cho et al. 1992). However in some cases, the efficiency of these systems is limited and generally its removing capacity is not constant (Wani et al. 1997). The use of biofilms generated with single bacterial cultures has been proposed for improving the efficiency and removal capacities of the biotrickling filters. Chemoheterotrophic microorganisms such as Pseudomonas acidovorans DMR-11 and Pseudomonas putida show degrading activity of $\mathrm{H}_{2} \mathrm{~S}$ and organic sulfur compounds. Bacteria from the genus Acidithiobacillus, such as $A$. thiooxidans that use $\mathrm{H}_{2} \mathrm{~S}$ as energy source, seem to be appropriate because of their low nutritional requirements (Cho et al. 2000; Sercu et al. 2005). The inoculation of biotrickling systems with single cultures leads to the shortening and even the absence of bacterial lag phase, as well as to the increase in the efficiency for removing $\mathrm{H}_{2} \mathrm{~S}$ and other organosulfur compounds during a stable operation. T. thioparus strains $\mathrm{CH} 11$ (Chung et al. 1997) and T. thioparus DW44 (Cho et al. 1992) shown high efficiency for removing $\mathrm{H}_{2} \mathrm{~S}$, being also able to degrade methanethiol, dimethylsulfide and dimethyldisulfide, and to use carbon disulfide as energy source (Smet et al. 1998). Other bacterial species that have been evaluated for the removal of sulfur reduced compounds are $T$. denitrificans (Sublette and Sylvester, 1987), A. ferrooxidans (Pagella and De Faveri, 2000), T. novellus (Cha et al. 1999), and $A$. thioxidans (Oprime et al. 2001). There is no comparison in the literature about the performance of biotrickling filters inoculated with different microorganism for the bioxidation of $\mathrm{H}_{2} \mathrm{~S}$.

Various materials have been used to support biofilms of Thiobacillus, among them polypropylene rings (Tanji et al. 1989), polystyrene foam, diatomaceous earth, ceramics, polystyrene mixed with active carbon, pellets of synthetic materials and perlite (Cox et al. 1997). In general, porous and non hydrophobic surfaces with high specific surface seem to facilitate or promote colonization by microorganisms and the subsequent formation of biofilms 


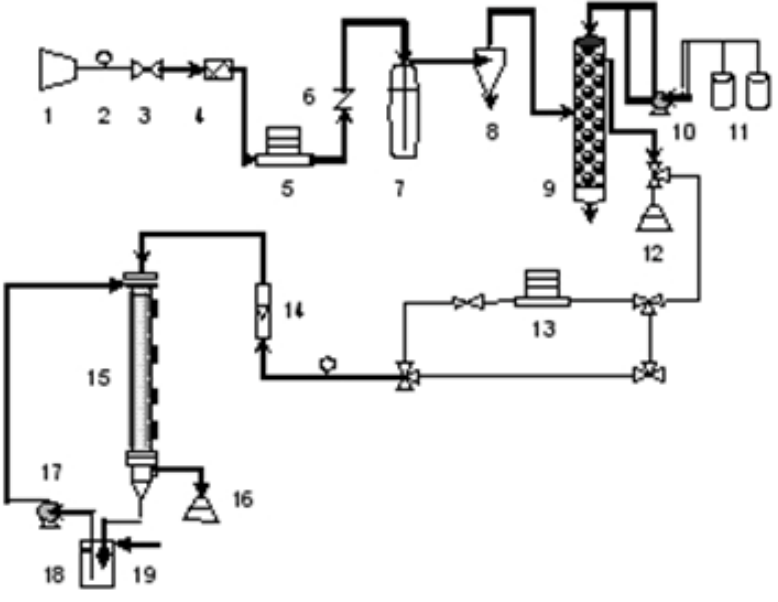

Figure 2. Laboratory-scale experimental biotrickling filter system. (1) Air compressor; (2) Pressure gauge; (3) Needle Valve; (4) Air filter; (5) Mass flow controller; (6) Check valve; (7) Humidification; (8) Mist removal chamber; (9) $\mathrm{H}_{2} \mathrm{~S}$ generator; (10) Peristaltic pump; (11) Solutions of $\mathrm{Na}_{2} \mathrm{~S}$ and $\mathrm{HCl}$; (12) Lead acetate solution; (13) Mass flow controller; (14) Flowmeter; (15) Biotrickling filter; (16) Air outlet; (17) Recycling pump; (18) Solution recycle; (19) Solution make-up.

(Chitwood and Devinny, 2001). Since these materials offer different characteristics for bacterial growth and for the operating conditions, it is important to develop analytical techniques to evaluate and compare their behaviour.

This article reports the performance in the bioxidation of $\mathrm{H}_{2} \mathrm{~S}$ using biotrickling filters inoculated with $T$. thioparus operated at neutral $\mathrm{pH}$ conditions, and a biotrickling filter inoculated with $A$. thiooxidans in an acid environment. The selection of the supporting material was made by using respirometry as an index of the sulfur oxidizing capacity of the biofilm formed on three materials: (i) volcanic stones (tezontle (TZ)); (ii) polypropylene rings and (iii) polyvinilclorure (PVC).

\section{MATERIALS AND METHODS}

\section{Microorganisms}

Thiobacillus thioparus (ATCC 23645) and Acidithiobacillus thiooxidans (ATCC 19377) were used to inoculate the solid supports and to initiate the generation of the biofilms in the biotrickling filters. The liquid medium used to culture $T$. thioparus, was a variation of the Thiosulfate medium (ATCC 290), the composition in $\mathrm{g} \mathrm{L}^{-1}$ was: $\mathrm{Na}_{2} \mathrm{HPO}_{4} * 7 \mathrm{H}_{2} \mathrm{O} 2.27 ; \mathrm{KH}_{2} \mathrm{PO}_{4} 1.8 ; \mathrm{MgCl}_{2} * 7 \mathrm{H}_{2} \mathrm{O} 0.1$; $\left(\mathrm{NH}_{4}\right)_{2} \mathrm{SO}_{4} \quad 1.98 ; \quad \mathrm{MnCl}_{2} * \mathrm{H}_{2} \mathrm{O} \quad 0.023 ; \mathrm{CaCl}_{2} \quad 0.03$; $\mathrm{FeCl}_{3} * 6 \mathrm{H}_{2} \mathrm{O} 0.033 ; \mathrm{Na}_{2} \mathrm{CO}_{3} 1 ; \mathrm{Na}_{2} \mathrm{~S}_{2} \mathrm{O}_{3} * 5 \mathrm{H}_{2} \mathrm{O} 15.69$ and pH 6.8. The composition of the liquid culture medium used to growth $A$. thiooxidans was $\left(\mathrm{g} \mathrm{L}^{-1}\right): \mathrm{KCl} 0.1 ; \mathrm{K}_{2} \mathrm{HPO}_{4} 0.5$; $\mathrm{Ca}\left(\mathrm{NO}_{3}\right)_{2} 0.01 ; \mathrm{MgSO}_{4} * 7 \mathrm{H}_{2} 0$ 0.5; $\mathrm{S}^{\mathrm{o}} 10$ and $\mathrm{pH} 2$ - 4.

\section{Selection of the support}

A continuous culture of $T$. thioparus was set up in a bioreactor, using a volume of $1 \mathrm{~L}$ and a dilution rate (D) of $0.03 \mathrm{~h}^{-1}, 1 \mathrm{vvm}$ of aeration, and controlling the $\mathrm{pH}$ at 6.0 and the temperature at $30^{\circ} \mathrm{C}$. The formation of the biofilm on the solid supports tested was conducted by feeding the outlet stream of the continuous culture from the top of three glass columns connected in series, each one packed with one of the following supporting materials: polyethylene rings, pieces of PVC, and porous volcanic stones (TZ). A diagram of this system is shown in Figure 1.

The activity of the biofilm formed on the supporting materials was evaluated by respirometry measuring the ability of the biomass to oxidize thiosulfate using an oxymeter (Yellow Spring Instrument, USA), that was calibrated with distilled water saturated with oxygen. The biomass was released from the supporting material using ultrasound in a solution $0.85 \% \mathrm{p} / \mathrm{v}$ of $\mathrm{NaCl}$. The suspended biomass was washed, centrifuged and resuspended three times to remove the remaining thiosulfate in the solution. The last pellet was suspended in a fresh medium without thiosulfate to obtain a final concentration of $10 \mathrm{~g} \mathrm{~L}^{-1}$ of protein content. $1 \mathrm{~mL}$ of cell suspension was used for the respirometry determinations. The rates of oxygen consumption were calculated taking into account the endogenous respiration and chemical oxidation measuring the oxygen consumption without cell suspension. Observations of the biofilm were made by scanning electron microphotography (Electronic microscope JOEL, model 5410).

\section{Biofiltration experiments}

Two biotrickling filter were set up using acrylic columns of $50 \mathrm{~mm}$ of inner diameter and $600 \mathrm{~mm}$ height. The column was filled with polyethylene rings (Kaldness MilijOteknology AS, Norway), the density of the support is $280 \mathrm{~kg} \mathrm{~m}^{-3}$, specific surface $340 \mathrm{~m}^{2} \mathrm{~m}^{-3}$ and it has a $73 \%$ of free volume.

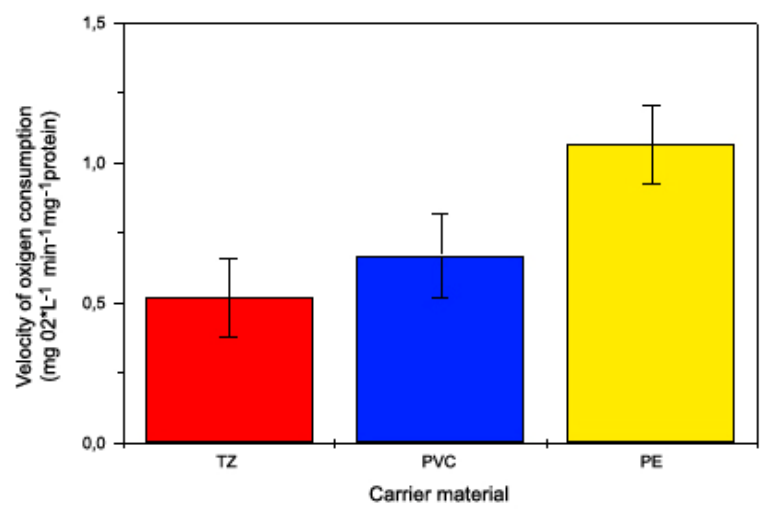

Figure 3. Oxidation rate of thiosulfate $(10 \mathrm{~g} / \mathrm{L})$ by the biomass detached from TZ, PVC and Polyethilene rings (PE), at $30^{\circ} \mathrm{C}$ and $\mathrm{pH} 6,0$. 

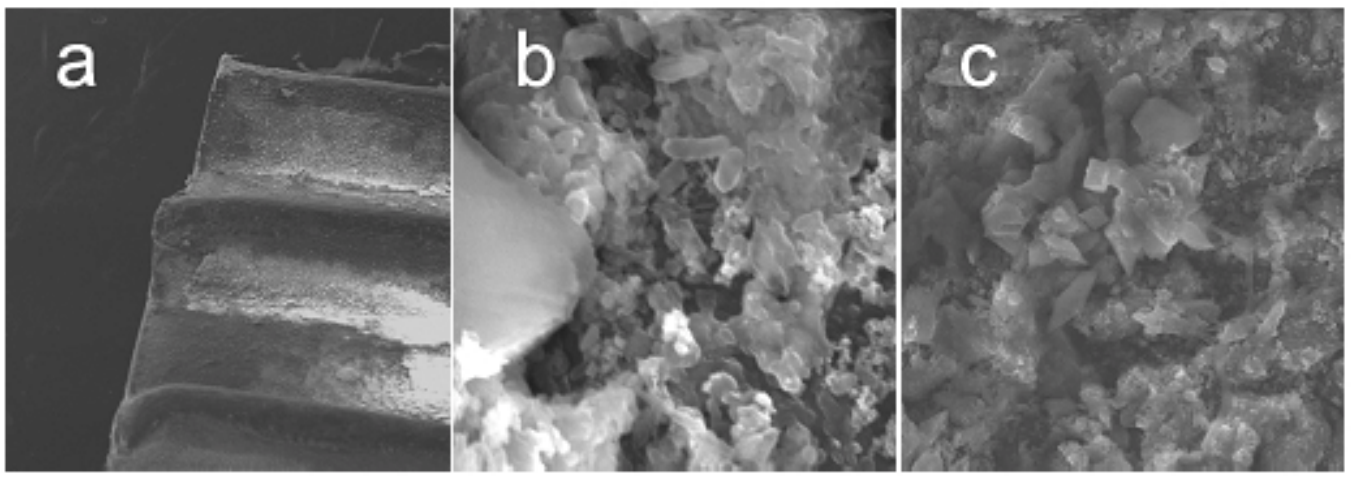

Figure 4. Scanning electron microphotograph of biofilm generated on polyethylene rings by $T$. thioparus.

The experimental setup is described in Figure 2. Teflon was used for all fittings, connections and tubing. The control of the flow was made by using needle valves and a flow mass controller (Aalborg Model GFC17, USA). The air was supplied by a compressor (Montecarlo, Model 24I ABAC, Spain), and the air was filtered and humidified by bubbling in an absorption column. $\mathrm{H}_{2} \mathrm{~S}$ was continuously generated in a column by the reaction between solutions of $\mathrm{Na}_{2} \mathrm{~S}$ and $\mathrm{HCl} . \mathrm{H}_{2} \mathrm{~S}$ was transported to the biotrickling filter by an humidified air flow.

The biotrickling filter packed with polyethylene rings was inoculated with a continuous culture of the corresponding bacteria under similar conditions, excepting the $\mathrm{pH}$, that was controlled in the range of optimal for growth in each case; 5,5-7,0 for $T$. thioparus, and 1,8-2,5 for $A$. thiooxidans. After 30 days the biofilms were clearly observed on the surface of the polyethylene rings. When the feed of $\mathrm{H}_{2} \mathrm{~S}$ started the liquid recirculated through out the column was the culture medium without the energy source.

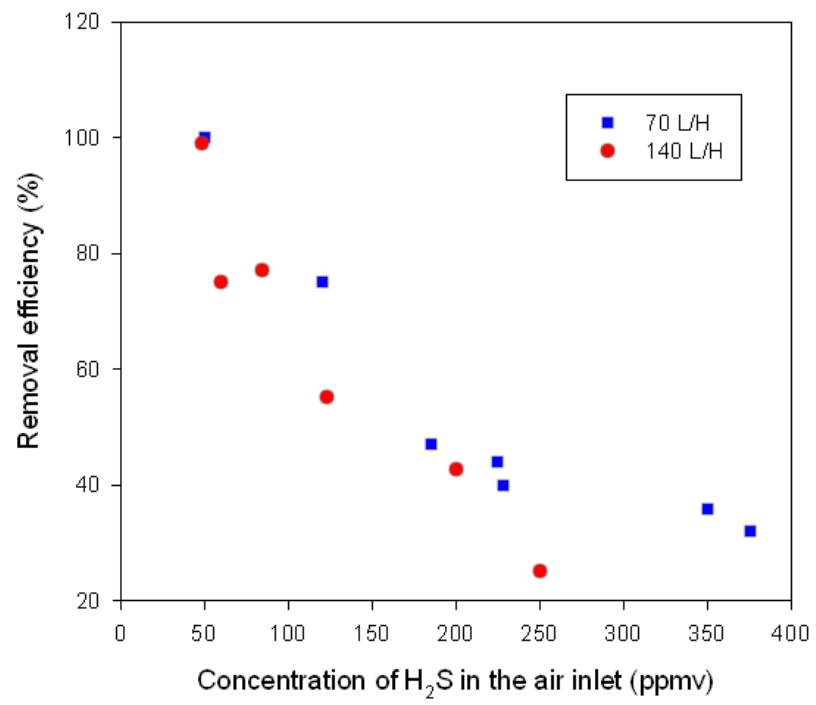

Figure 5. Removal efficiencies of $\mathrm{H}_{2} \mathrm{~S}$ in a biotrickling filter using a biofilm of $T$. thioparus $(\mathrm{pH} \mathrm{5,5-7,0)}$.

\section{Analytical methods}

$\mathrm{H}_{2} \mathrm{~S}$ was determined by a gas chromatograph (Perkin Elmer, USA) equipped with a detector for thermal conductivity, using a column packed with Super Q 80/100 (Alltech, USA). Helium was used as the carrier gas at a flow rate of $40 \mathrm{ml} / \mathrm{min}$ and the temperatures used in the injector, oven, and detector were $70^{\circ} \mathrm{C}, 80^{\circ} \mathrm{C}$ and $90^{\circ} \mathrm{C}$, respectively.

The biomass growing over the solid supports was suspended in liquid using ultrasound. In liquid culture the suspended biomass was determined by turbidimetry or by their total protein content. In both cases, the culture was previously filtered to remove colloidal sulfur. Protein content was determined to the suspension by using the method of Lowry (Lowry et al. 1951).

\section{RESULTS AND DISCUSSION}

The levels of oxygen consumption indicated that the oxidation of thiosulfate was higher with biomass suspended from biofilms formed by $T$. thioparus growing over polyethylene rings (Figure 3). Volcanic rocks (TZ) always exhibited the highest biomass production, a fact that probably due to the irregular surface and its highly porous structure, but the accumulation of biomass and the elementary sulfur generated as a product of the biological oxidation of thiosulfate obstructed the column and it causes the canalization of the flow through it. These conditions might have generated areas in the supporting material lacking in oxygen and nutrients, a fact that might explain the low activity showed, as a consequence of diffusional restrictions (Cox et al. 1997).

The higher rates of thiosulfate oxidation showed by cells detached from polyethylene rings may be attributed to the adsorbing properties of the surface of the material that leads to the development of a homogeneous biofilm, as shown by electron microscopy (Figure 4). This fact might result in a higher availability of oxygen and nutrients for the immobilized cells thus maintaining them metabolically active. 


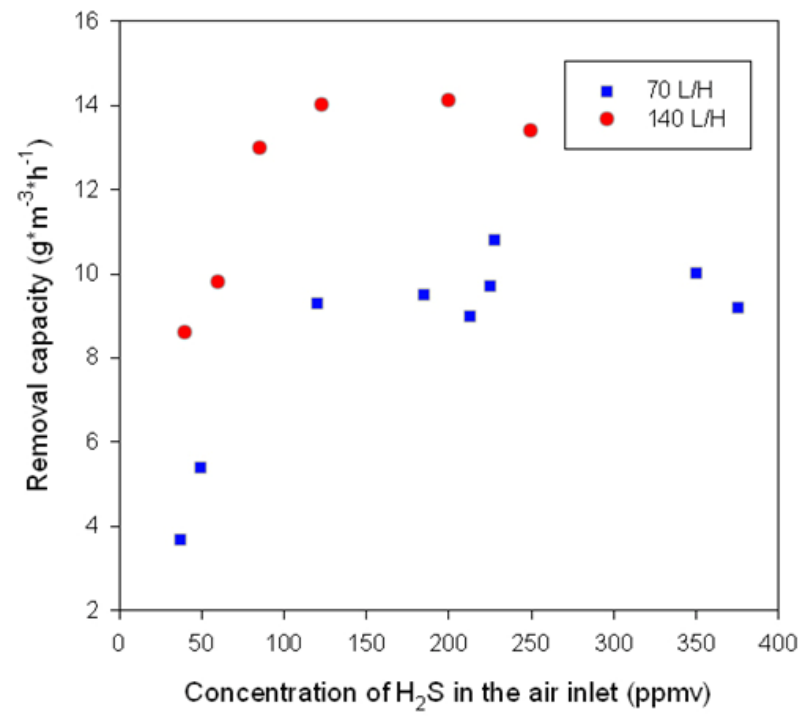

Figure 6. Removal capacity in a biotrickling filter using a biofilm of $T$. thioparus (pH 5,5-7,0).

Figure 4 shows a microscopy photograph of the biofilm formed by $T$. thioparus. In Figure $4 \mathrm{a}$ considerable development of bacteria associated to the rings is observed, whereas in Figure $4 \mathrm{~b}$ and Figure $4 \mathrm{c}$ abundant elementary sulfur generated on the surface of the polyethylene ring was observed. This material was produced by oxidation of thiosulfate, producing crystals with their typical octahedral structure. The analysis of the secondary emission revealed that the elementary sulfur was present in an significant proportion $(34,72 \% \mathrm{p} / \mathrm{p})$. Similar results were obtained for A. thiooxidans.

Figure 5 and Figure 6 show the results obtained in the removal of $\mathrm{H}_{2} \mathrm{~S}$ when using the biotrickling filter with a biofilm formed by $T$. thioparus, operated at a range of $\mathrm{pH}$ between 5,5 and 7,0 as to provide the optimal conditions for growth. The maximal removal capacity attained in this bioreactor was $14 \mathrm{gS} \mathrm{m}^{-3} \mathrm{~h}^{-1}$ at $30 \mathrm{gS} \mathrm{m}^{-3} \mathrm{~h}^{-1}$ of inlet load, $47 \%$ of removal efficiency at a residence time of $26 \mathrm{sec}$.

Better results were obtained in the biotrickling filter inoculated with A. thiooxidans, and operated without $\mathrm{pH}$ control at high inlet concentrations of $\mathrm{H}_{2} \mathrm{~S}$. The results are shown in Figure 7 and Figure 8.

Removal efficiency of $100 \%$ were achieved for higher inlet concentration of $\mathrm{H}_{2} \mathrm{~S}$ (4600 and $982 \mathrm{ppmv}$ ) for $120 \mathrm{sec}$ and $45 \mathrm{sec}$ of residence time, respectively, therefore, better removal capacities were obtained as compared with $T$. thioparus. Also,complete oxidation of $\mathrm{H}_{2} \mathrm{~S}(100 \%)$ was achieved with an inlet load of $240 \mathrm{gS} \mathrm{m}^{-3} \mathrm{~h}^{-1}$ of inlet load. The highest removal capacity was $370 \mathrm{gS} \mathrm{m}^{-3} \mathrm{~h}^{-1}$ at $45 \mathrm{sec}$ of residence time, and $405 \mathrm{gS} \mathrm{m}^{-3} \mathrm{~h}^{-1}$ of inlet load $(91 \%$ of efficiency), which represents eliminations capacities of a similar level that previously reported by Cho et al. (2000), who obtained the best results using biotrickling filter packed with porous lava inoculated with $A$. thiooxidans $\left(428 \mathrm{gS} \mathrm{m}^{-3} \mathrm{~h}^{-1}\right)$.

Both values obtained in biotrickling filters inoculated with A. thiooxidans are considerably higher than the capacities reported in biofiltration systems packed with natural carriers (Cho et al. 1992; Yang and Allen, 1994; Wani et al. 1999; Elias et. al. 2002; Oyarzún et al. 2003), possibly due to the possibility to drain sulfur and sulfate.

\section{CONCLUDING REMARKS}

The draining of cellular suspension appears to be a simple and efficient system for the generation of biofilms, Volcanic stones showed favourable characteristics for microbial colonization, although the excessive accumulation of biomass constitutes a disadvantage in the use of biotrickling filters, since obstruction of the reactor bed and canalization problems could be generated with this support.

The determination of the biooxidation capacity of the biomass released from the biofilm offer a suitable criterion of carrier selection for biotrickling filters, since they constitute an approach for the metabolic state of the cells within the biofilm. Polyethylene rings exhibit the most suitable properties as supporting material in a biotrickling filter, as shown by the higher rates of thiosulfate oxidation and homogeneous cellular colonization of the carriers.

The removal capacity of the biotrickling filter inoculated with $T$. thioparus operating in the range of $\mathrm{pH}$ between $\mathrm{pH}$ 5.5-7.0, the range allowing the maximum reported growth rate, is lower than the removal capacity of acidophilic $A$. thiooxidans showing that $A$. thiooxidans is the most suitable microorganism for the biooxidation of $\mathrm{H}_{2} \mathrm{~S}$ in biotrickling filters.

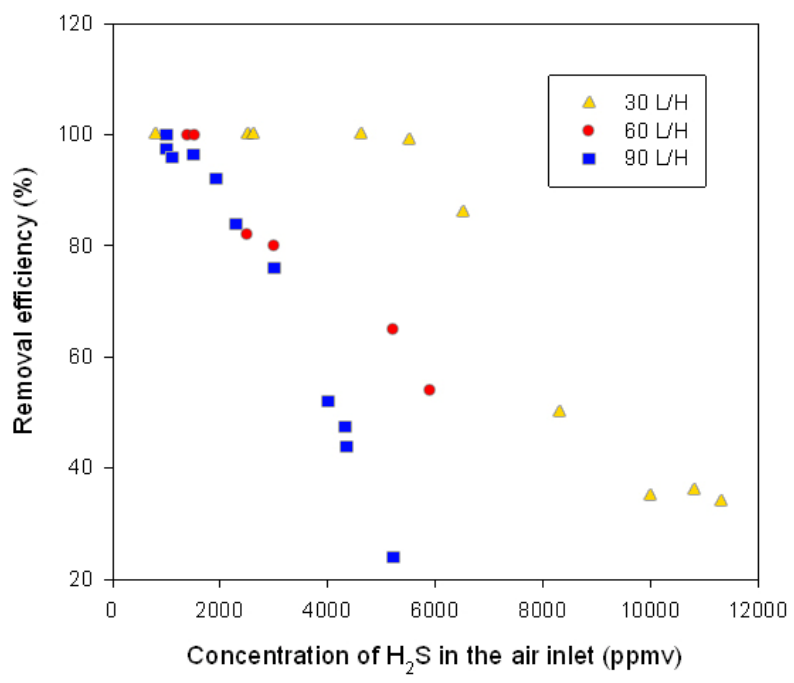

Figure 7. Removal efficiencies in a biotrickling filter inoculated with $A$. thiooxidans. 


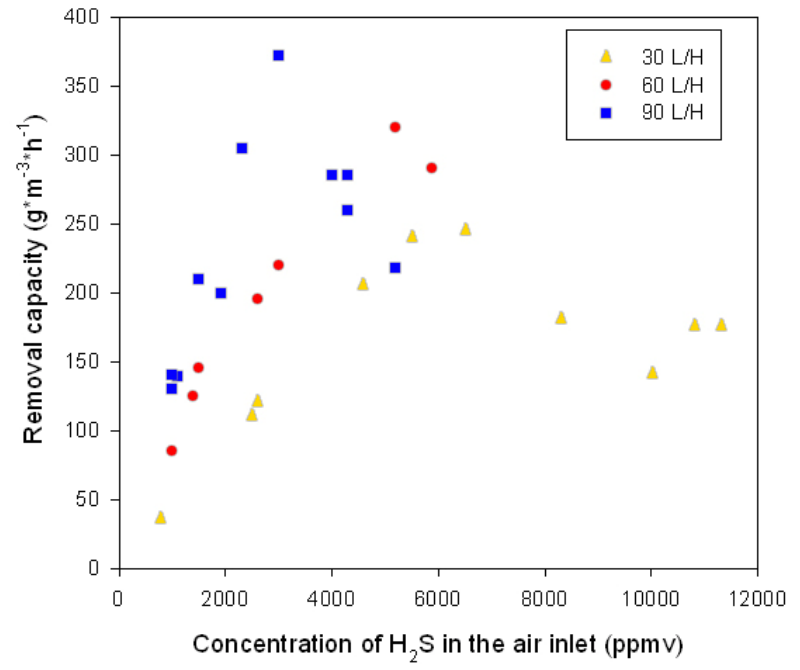

Figure 8. Removal capacity of a biotrickling filter inoculated with $A$. thiooxidans.

An important advantage of the acid biotrickling filter is that it does not require an exhaustive $\mathrm{pH}$ control of the liquid media as it occurs in the biotrickling filter inoculated with T. thioparus, in which any $\mathrm{pH}$ variation produces a drastic change on the $\mathrm{H}_{2} \mathrm{~S}$ biooxidation efficiency.

\section{ACKNOWLEDGMENTS}

The authors want to acknowledge the support given by Prof. Sergio Revah from the Universidad Autónoma Metropolitana - Iztapalapa, Mexico D.F.

\section{REFERENCES}

ALONSO, Cristian; SUIDAN, Makram T.; SORIAL, George A.; SMITH, F. Lee; BISWAS, Pratim; SMITH, Paul J. and BRENNER, Richard C. Gas treatment in trickle-bed biofilters: biomass, how much is enough? Biotechnology and Bioengineering, June 1997, vol. 54, no. 6, p. 583-594.

CHA, Jin Myung; CHA, Wol Suk and LEE, Jung-Heon. Removal of organo-sulfur odour compounds by Thiobacillus novellus SRM, sulfur-oxidizing microorganism. Process Biochemistry, September 1999, vol. 34, no. 6-7, p. 659-665.

CHITWOOD, Derek E. and DEVINNY, Joseph S. Treatment of mixed hydrogen sulfide and organic vapors in a rock medium biofilter. Water Environmental Research, July-August 2001, vol. 73, no. 4, p. 426-435.

CHO, Kyeoung-Suk; HIRAI, Mitsuyo and SHODA, Makoto. Enhanced removal efficiency of malodorous gases in a pilot-scale peat biofilter inoculated with Thiobacillus thioparus DW44. Journal of Fermentation and Bioengineering, 1992, vol. 73, no. 1, p. 46-50.
CHO, Kyeoung-Suk; RYU, Hee Wook and LEE, Nae Yoon. Biological deodorization of hydrogen sulfide using porous lava as a carrier of Thiobacillus thiooxidans. Journal of Bioscience and Bioengineering, 2000, vol. 90, no. 1, p. 25-31.

CHUNG, Ying-Chien; HUANG, Chilhpin and TSENG, Ching-Ping. Removal of hydrogen sulfide by immobilized Thiobacillus sp. strain $\mathrm{CH} 11$ in a biofilter. Journal of Chemical Technology and Biotechnology, May 1997, vol. 69 , no. 1 , p. $58-62$.

COX, H.H.J.; MOERMAN, R.E.; VAN BAALEN, S.; VAN HEININGEN, W.N.M.; DODDEMA, H.J. and HARDER, W. Performance of a styrene-degrading biofilter containing the yeast Exophiala jeanselmei. Biotechnology and Bioengineering, February 1997, vol. 53, no. 3, p. 259266.

DESHUSSES, Marc A. Biological waste air treatment in biofilters. Current Opinion in Biotechnology, June 1997, vol. 8 , no. 3, p. 335-339.

ELIAS, A.; BARONA, A.; ARREGUY, A.; RÍOS, J.; ARANGUIZ, I. and PEÑAS, J. Evaluation of a packing material for the biodegradation of $\mathrm{H}_{2} \mathrm{~S}$ and product analysis. Process Biochemistry, March 2002, vol. 37, no. 8, p. 813-820.

GABRIEL, David and DESHUSSE, Marc A. Performance of a full scale biotrickling filter treating $\mathrm{H}_{2} \mathrm{~S}$ at a gas contact time of 1.6 to 2.2 seconds. Environmental Progress, July 2003, vol. 22, no. 2, p. 111-118.

HIRAI, Mitsuyo; OHTAKE, Masatoshi and SHODA, Makoto. Removal kinetics of hydrogen sulfide, methanethiol and dimethyl sulfide by peat biofilter. Journal of Fermentation and Bioengineering, 1990, vol. 70, no. 5, p. 334-339.

JENSEN, Anders B. and WEBB, Colin. Treatment of $\mathrm{H}_{2} \mathrm{~S}-$ constaining gases: A review of microbiological alternatives. Enzyme and Microbial Technology, January 1995, vol. 17, no. 1, p. 2-10.

KENNES, Christian and THALASSO, Fréderic. Waste gas biotreatment technology. Journal of Chemical Technology and Biotechnology, 1998, vol. 72, no. 4, p. 303-319.

LOWRY, Oliver H.; ROSEBROUGH, Nira J.; FARR, A. Lewis and RANDALL, Rose J. Protein Measurement with the folin phenol reagent. The Journal of Biological Chemistry, November 1951, vol. 193, no. 1, p. 265-275.

OPRIME, Maria E.A.G.; GARCIA, Oswaldo and CARDOSO, Arnaldo A. Oxidation of $\mathrm{H}_{2} \mathrm{~S}$ in acid solution by Thiobacillus ferroxidans and Thiobacillus thiooxidans. Process Biochemistry, October 2001, vol. 37, no. 2, p. 110114. 
OYARZÚN, Patricio; ARANCIBIA, Fernando; CANALES, Christian and AROCA, Germán. Biofiltration of high concentration of hydrogen sulfide using Thiobacillus thioparus. Process Biochemistry, October 2003, vol. 39, no. 2, p. 165-170.

PAGELLA, C. and DE FAVERI, D.M. $\mathrm{H}_{2} \mathrm{~S}$ gas treatment by iron bioprocess. Chemical Engineering Science, June 2000, vol. 55, no. 12 , p. 2185-2194.

RUOKOJARVI, A.; AATAMILA, M.; HARTIKAINEN, T.; OLKKONEN, M.; SALMI, J.; RUUSKANEN, J. and MARTIKAINEN, P. Removal of dimethyl sulphide from off-gas mixtures containing hydrogen sulphide and methanethiol by a biotrickling filter. Environmental Technology, October 2000, vol. 21, no. 10, p. 1173-1180.

SERCU, B.; NÚÑEZ, D.; VAN LANGENHOVE, H.; AROCA, G. and VERSTRAETE, W. Operational and microbiological aspects of a bioaugmented two-stage biotrickling filter removing hydrogen sulfide and dimethyl sulfide. Biotechnology and Bioengineering, April 2005, vol. 90 , no. 2, p. 259-269.

SMET, E.; LENS, P. and VAN LANGENHOVE, $H$. Treatment of waste gases contaminated with odorous sulfur compounds. Critical Reviews in Environmental Science and Technology, January 1998, vol. 28, no. 1, p. 89-117.

SUBLETTE, Kerry L. and SYLVESTER, Nicholas D. Oxidation of hydrogen sulfide by Thiobacillus denitrificans: desulfurization of natural gas. Biotechnology and Bioengineering, February 1987, vol. 29, no. 2, p. 249257.

TANJI, Yasunori; KANAGAWA, Takahiro and MIKAMI, Eiichi. Removal of dimethyl sulfide, methyl mercaptan, and hydrogen sulfide by immobilized Thiobacillus thioparus TK-m. Journal of Fermentation and Bioengineering, 1989, vol. 67 , no. 4 , p. $280-285$.

WANI, Altaf H.; BRANION, Richard M.R. and LAU, Anthony K. Biofiltration: A promising and cost-effective control technology for odours, VOCs and air toxics. Journal of Environmental Science and Health, Part A Environmental Science and Engineering, 1997, vol. 32, no. 7, p. 2027-2055.

WANI, Altaf H.; LAU, Anthony K. and BRANION, Richard M.R. Biofiltration control of pulping odourshydrogen sulfide: performance, macrokinetics and coexistence effects of organo-sulfur species. Journal of Chemical Technology and Biotechnology, January 1999, vol. 74, no. 1, p. 9-16.

YANG, Y. and ALLEN, E. Biofiltration control of hydrogen sulfide 1. Design and operational parameters. Journal of Air and Waste Management Association, 1994, vol. 44, no. 7, p. 863-868. 